\title{
UPAYA MENINGKATKAN HASIL BELAJAR MATEMATIKA DENGAN \\ MENGGUNAKAN MODEL PEMBELAJARAN SNOWBALL TROWING DAN METODE DEMONSTRASI DENGAN BERBANTUAN MEDIA KONKRET KELAS \\ IIIB DI SDN 8 LANGKAI PALANGKA RAYA \\ TAHUN PELAJARAN 2017/2018
}

Oleh : NOR SAFITRI*Misyanto, M.Pd

\begin{abstract}
ABSTRAK
Penelitian ini bertujuan (1) mengetahui aktivitas peserta didik pada saat pembelajaran Matematika dengan menggunakan model Snowball Trowing dan metode Demonstrasi dengan berbantuan media Konkret, (2) mengetahui peningkatan hasil belajar Matematika dengan menggunakan model Snowball Trowing dan metode Demonstrasi dengan berbantuan media Konkret.

Penelitian ini di lakukan pada minggu ke-2 bulan Maret 2018 yang berlokasi di SDN 8 Langkai Palangka Raya, Jl.Patih Rumbih Palangka Raya-Kalimantan Tengah. Jenis penelitian ini adalah Penelitian Tindakan Kelas (PTK) dengan subjek penelitian seluruh peserta didik kelas III-b SDN 8 Langkai Palangka Raya yang berjumlah 20 peserta didik. Peserta didik laki-laki berjumlah 11 orang dan peserta didik perempuan berjumlah 9 orang. Tehnik penggumpulan data pada penelitian ini menggunakan tes dan observasi. Analisis data menggunakan analisis data kualitatif dan kuantitatif.

Hasil penelitian ini menunjukan bahwa (1) penggunaan model Snowball Trowing dan metode Demonstrasi dengan berbantuan media Konkret aktivitas peserta didik meningkat yang ditunjukan dengan perolehan skor hasil pengamatan di atas 3, (2) penggunaan model Snowball Trowing dan metode Demonstrasi dengan berbantuan media Konkret dapat meningkatkan hasil belajar peserta didik yang ditunjukan dengan perolehan rata-rata nilai 67,3 pada siklus I dan meningkat menjadi 8,28 pada siklus II. Ketuntasan belajar secara klasikal juga mengalami peningkatkan dengan nilai $75 \%$ pada siklus I meningkat menjadi 96\% pada siklus II.
\end{abstract}

Kata Kunci: Hasil Belajar Matematika, Model Snowball Trowing, Metode Demonstrasi, Media Konkret. 


\section{PENDAHULUAN}

Pendidikan adalah usaha sadar dan terencana untuk mewujudkan suasana belajar dan proses pembelajaran agar peserta didik secara aktif mengembangkan potensi dirinya untuk memiliki kekuatan spritual keagamaan, pengendalian diri, kpribadian, kecerdasaan, ahlak mulia ,serta keterampilan yang diperlukan dirinya, masyarakat, bangsa dan negara.

Belajar Matematika merupakan tentang konsep-konsep dan struktur abstrak yang terdapat dalam Matematika serta mencari hubungan antara konsep-konsep dan struktur Matematika. Tujuan belajar Matematika di SD agar peserta didik memiliki kemampuan sebagai berikut, (1) memahami konsep Matematika, menjelaskan keterkaitan antara konsep dan mengaplikasikan konsep atau alogaritma, secara luwes, akurat, efesien, dan tepat dalam pemecahan masalah.

Menggunakan penalaran pada pola dan sifat,melakukan manipulasi matematika dalam membuat generalisasi, menyusun bukti,atau menjelaskan gagasan dan pernyataan Matematika. (3) memecahkan masalah meliputi kemampuan memahami masalah, merancang model Matematika, menyelesaikan model dan menafsirkan solusi yang di peroleh. (4) mengkomunikasikan gagasan dengan simbol, tabel, diagram, atau media lain untuk memperjelas masalah. (5) memiliki sikap menghargai kegunaan Matematika dalam kehidupan. (Sekolah Dasar.Net diakses 29 Desember 2017)
Berdasarkan hasil observasi peneliti di SDN 8 Langkai Palangka Raya di kelas IIIB pada tanggal 30 Oktober 2017, kurikulum yang digunakan adalah K13 dan mata pelajaran Matematika materi Pecahan saya mendapati fenomena peserta didik mengalami kebosanan, kejenuhan dan kurang fokus dalam proses pembelajaran sehingga peserta didik sukar untuk berkonsentrasi dalam proses pembelajaran, sehingga peserta didik kurang memahami pembelajaran Matematika Hal ini tampak pada hasil belajar matematika peserta didik. Dari hasil wawancara dengan guru jumlah peserta didik 19 orang $12(75 \%)$ siswa yang mendapatkan nilai di bawah KKM dan 7 (25\%) siswa yang mendapat nilai memenuhi KKM. KKM matematika di SDN 8 Langkai Palangka Raya adalah 65.

Melihat fenomena tersebut maka penelitian ini penting agar menambah wawasan guru dalam pembelajaran supaya guru mampu menerapkan model pembelajaran yang nantinya untuk menarik minat dan perhatian peserta didik.

Berdasarkan fenomena di atas peneliti tertarik melakukan penelitian dengan judul "Upaya Meningkatkan Hasil Belajar Matematika dengan Menggunakan Model Pembelajaran Snowball Trowing dan Metode Demonstrasi dengan Berbatuan Media Konkrit pada kelas IIIB Di SDN 8 Langkai Palangka Raya Tahun Pelajaran 2017/2018" Menurut Miftahul (2013:226) Model Snowball Trowing merupakan "pembelajaran yang diadopsi pertama kali dari game fisik dimana segumpalan salju dilempar dengan memukul orang lain". 
Tunas Jurnal Pendidikan Guru Sekolah Dasar, Juni 2019, Volume 1 Nomor 2, (42-54) ISSN : 2477-6076

Menurut Suprijono (2011:8) Snowball Trowing adalah suatu cara penyajian bahan pelajaran dimana murid dibentuk dalam beberapa kelompok yang heterogen kemudian masing-masing kelompok dipilih ketua kelompok untuk mendapat tugas dari guru lalu masingmasing murid membuat pertanyaan yang dibentuk seperti bola kemudian dilempar kemurid lain yang masing-masing murid menjawab pertanyaan dari bola yang diperoleh.

Adapun langkah-langkah model pembelajaran snowball Throwing menurut Miftahul (2013:226) adalah sebagai berikut

a) Guru menyampaikan materi yang akan disajikan.

b) Guru membentuk kelompok-kelompok dan memanggil masing-masing ketua kelompok untuk memberikan penjelasan tentang materi.

c) Masing-masing ketua kelompok kembali kekelompoknya masing-masing kemudian menjelaskan materi yang disampaikan guru kepada teman sekelompoknya.

d) Masing-masing siswa diberikan satu lembar kertas kerja untuk menuliskan satu pertanyaan apa saja yang menyangkut materi yang sudah dijelaskan oleh ketua kelompok.

e) Siswa membentuk kertas tersebut seperti bola dan dilempar dari satu siswa ke siswa yang lain selama+15 menit.

f) Setelah siswa mendapat satu bola, ia diberi kesempatan untuk menjawab pertanyaan yang ditulis dalam kertas tersebut secara bergantian.

g) Guru mengevaluasi dan menutup pembelajaran.

Menurut Saminanto(2010:37) langkahlangkah model pembelajaran Snowball Trowing adalah sebagai berikut :

a) Guru menyampaikan materi yang akan disajikan, dan KD yang ingin dicapai.

b) Guru membentuk peserta didik berkelompok, lalu memanggil masingmasing ketua kelompok untuk mem berikan penjelasan tentang materi.

c) Masing-masing ketua kelompok kembali kekelompok nya masing-masing, kemudian menjelaskan materi yang disampaikan oleh guru kepada temannya.

d) Kemudian masing-masing peserta didik diberikan satu lembar kertas kerja, untuk menuliskan satu pertanyaan apa saja yang menyangkut materi yang sudah dijelaskan oleh ketua kelompok.

e) Kemudian kertas yang berisi pertanyaan tersebut dibuat seperti bola dan dilempar dari satu peserta didik ke peserta didik yang lain selama \pm 5 menit.

f) Setelah peserta didik dapat satu bola/satu pertanyaan diberikan kesempatan kepada peserta didik untuk menjawab pertanyaan yang tertulis dalam kertas berbentuk bola tersebut secara bergantian.

g) Evaluasi.

Berdasarkan pendapat para ahli diatas maka dapat disimpulkan bahwa langkah-langkah Snowball Trowing adalah sebagai berikut : 
Tunas Jurnal Pendidikan Guru Sekolah Dasar, Juni 2019, Volume 1 Nomor 2, (42-54) ISSN : 2477-6076

a) Guru menyampaikan materi yang akan disajikan.

b) Guru membentuk peserta didik berkelompok, lalu memanggil masingmasing ketua kelompok untuk mem berikan penjelasan tentang materi.

c) Masing-masing ketua kelompok kembali kekelompoknya masing-masing kemudian menjelaskan materi yang disampaikan guru kepada teman sekelompoknya.

e) Kemudian masing-masing peserta didik diberikan satu lembar kertas kerja, untuk menuliskan satu pertanyaan apa saja yang menyangkut materi yang sudah dijelaskan oleh ketua kelompok.

f) Siswa membentuk kertas tersebut seperti bola dan dilempar dari satu siswa ke siswa yang lain selama+15 menit.

g) Setelah peserta didik dapat satu bola/satu pertanyaan diberikan kesempatan kepada peserta didik untuk menjawab pertanyaan yang tertulis dalam kertas berbentuk bola tersebut secara bergantian.

h) Evaluasi

Adapun kelebihan model pembelajaran snowball trowing menurut Miftahul (2013:226) adalah sebagai berikut;"

a) Melatih kesiapan siswa,

b)Saling memberikan pengetahuan".

Adapun kekurangan model pembelajaran snowball trowing menurut Miftahul (2013:226) adalah sebagai berikut; a) Pengetahuan tidak luas hanya berkutat pada pengetahuan sekitar siswa,

b) Tidak efektif'.

Jadi kelebihan dari model pembelajaran Snowball Trowing adalah sebagai berikut :

1) Bisa melatih kesiapan belajar siswa.

2) Siswa bisa memberikan pengetahuan kepada teman-temannya.

Jadi kekurangan dari model pembelajaran Snowball Trowing adalah sebagai berikut :

1) Pengetahuan yang siswa dapat tidak luas.

2) Pembelajaran tidak efektif

Metode demonstrasi menurut Abdul (2014:197) adalah "metode penyajian pelajaran dengan memperagakan dan mempertunjukan kepada siswa tentang suatu proses, situasi, atau benda tertentu, baik sederhana atau sekedar tiruan". Menurut Imas dan Berlin (2015:84)

Metode demonstrasi adalah sebuah upaya atau praktek dengan menggunakan peragaan yang di tunjukan pada siswa lebih mudah dalam memahami dan mempraktekan apa yang telah di peroleh dan didapatkan ketika berhasil mengatasi suatu permasalahan ketika ada perbedaan.

Hal ini juga berarti bahwa strategi demonstrasi adalah cara penyajian pelajaran dengan memperagakan dan mempertunjukan suatu proses, situasi atau benda tertentu yang sedang dipelajari baik dalam bentuk sebenarnya maupun dalam bentuk tiruan 
Tunas Jurnal Pendidikan Guru Sekolah Dasar, Juni 2019, Volume 1 Nomor 2, (42-54) ISSN : 2477-6076

yang dipertunjukan oleh guru atau sumber belajar lain didepan seluruh siswa.

Menurut Miftahul (2012) kelebihan metode demonstrasi adalah sebagai berikut:

a) Dengan model pembelajaran demonstrasi, guru bisa membuat perhatian siswa menjadi terpusat, dan titik tekan dalam materi yang di anggap penting oleh guru dapat teramati.

b) Perhatian siswa akan lebih terpusat pada apa yang di demonstrasikan, jadi proses pembelajaran akan lebih terarahkan.

c) Dapat merangsang siswa untuk lebih aktif dalam mengikuti proses belajar.

d) Dapat menambah pengalaman anak didik.

e) Bisa membantu siswa ingat lebih lama tentang materi yang disampaikan.

f) Dengan mengurangi kesalahpahaman karena pengajar lebih jelas dan konkrit.

G) Dapat menjawab semua masalah yang timbul di dalam pikiran setiap siswa karena ikut serta berperan secara langsung.

Menurut Abdul (2014:199) kelebihan metode demonstrasi adalah sebagai berikut :

a) Melalui metode demonstrasi, terjadinya verbalisme akan dapat dihindari karena siswa disuruh langsung memerhatikan bahan pelajaran yang dijelaskan.

b) Proses pembelajaran akan lebih menarik karena siswa tak hanya mendengar, tetapi juga melihat peristiwa yang terjadi. c) Dengan cara mengamati secara langsung, siswa akan memiliki kesempatan untuk membandingkan antara teori dan kenyataan.

Dengan demikian kelebihan dari metode demonstrasi adalah sebagai berikut :

a) Membuat pengajaran menjadi lebih jelas dan lebih konkret.

b) Memusatkan perhatian peserta didik.

c)Lebih mengarahkan proses belajar peserta didik pada materi yang sedang dipelajari.

d) Lebih melekatkan pengalaman dan kesan sebagai hasil pembelajaran dalam diri peserta didik.

e) Membuat peserta didik lebih mudah memahami apa yang dipelajari.

f) Membuat proses pembelajaran lebih menarik.

g) Merangsang peserta didik untuk aktif mengamati dan menyesuaikan antara teori dengan kenyataannya.

h) Membantu peserta didik memahami dengan jelas jalannya suatu proses atau kerja suatu benda.

i) Memudahkan berbagai jenis penjelasan.

j) Memperbaikan kesalahan-kesalahan yang terjadi dari hasil ceramah melalui pengamatan dan contoh konkret dengan menghadirkan objek sebenarnya.

Menurut Abdul (2014) kekurangan metode demonstrasi adalah sebagai berikut :

a) Metode demonstrasi memerlukan persiapan yang lebih matang. 
Tunas Jurnal Pendidikan Guru Sekolah Dasar, Juni 2019, Volume 1 Nomor 2, (42-54)

ISSN : 2477-6076

b) Demonstrasi memerlukan peralatan, bahan-bahan, dan tempat yang memadai.

c) Demonstrasi memerlukan kemampuan dan keterampilan guru yang khusus sehingga guru dituntut untuk bekerja lebih profesional

Menurut Imas (2015:86) kekurangan metode demonstrasi adalah sebagai berikut :

a) Metode ini memerlukan waktu yang panjang.

b) Metode ini harus digunakan lengkap.

c) Memerlukan biaya mahal.

d) Memerlukan tenaga yang tidak sedikit.

e) Apabila peserta didik tidak aktif maka metode ini tidak efektif.

Adapun kekurangan dari metode demonstrasi adalah sebagai berikut :

a) Ia harus mengharuskan keterampilan guru secara khusus.

b) Tidak tersedianya fasilitas-fasilitas pendukung, seperti perlatan, tempat, dan biaya yang memadai di setiap kelas.

c) Memerlukan kesiapan dan perencanaan yang matang disamping waktu yang cukup panjang.

d) Kesulitan peserta didik terkadang untuk melihat dengan jelas benda yang akan dipertunjukan.

e) Sukar dimengerti bila di demonstrasikan oleh guru yang kurang menguasai materi atau barang yang didemonstrasikan.
Menurut Munadi (Yanti : 2013 ) menyatakan bahwa : Media konkret adalah segala sesuatu yang dapat menyampaikan dan menyalurkan pesan dari sumber secara terencana sehingga tercipta lingkungan belajar yang kondusif dimana penerimannya dapat melakukan proses belajar secara efesien dan efektif.

Menurut Jufry (2011) menyatakan bahwa : Benda nyata (real thing) merupakan alat bantu yang paling mudah penggunaanya, karena tidak perlu membuat persiapan selain langsung menggunakannya. Yang dimaksud dengan benda nyata sebagai media adalah penyimpanan informasi yang berupa benda atau subjek yang sebenarnya atau asli dan tidak mengalami perubahan yang berarti.

Berdasarkan pendapat diatas maka dapat diambil kesimpulan bahwa media konkret adalah suatu media yang dapat digunakan dalam suatu pembelajaran yang nyata terhadap peserta didik dan bisa juga menarik perhatian peserta didik untuk aktif dalam mengikuti pelajaran.

Kelebihan media konkret menurut Sumantri dan Permana (dalam Heryanto,2014:20) adalah sebagai berikut :

1) Membantu guru menyampaikan pesanpesan secara mudah kepada peserta didik.

2) Peserta didik dapat menguasai pesanpesan tersebut secara cepat dan akurat.

Menurut Mandjiono dalam Daryanto (2011:27)meenyatakan bahwa media konkret memiliki beberapa kelebihan antara lain: 
Tunas Jurnal Pendidikan Guru Sekolah Dasar, Juni 2019, Volume 1 Nomor 2, (42-54) ISSN : 2477-6076

1) Memberikan pengalaman secara langsung.

2) Menyajikan secara konkret dan menghindari verbalisme.

3) Dapat menujukan objek secara utuh, baik konstruksi maupun secara kerjanya.

4) Dapat menunjukan alur suatu proses secara jelas.

Jadi dapat ditarik kesimpulan bahwa kelebihan dari media konkret adalah sebagai berikut :

1) Membantu guru menyampaikan pesan secara mudah.

2) Menyajikan secara nyata kepada peserta didik.

3) Dapat menunjukan objek secara jelas.

Sedangkan kelemahan media konkret menurut Sumantri dan Permana (dalam Heryanto,2014:20) adalah sebagai berikut :

1) Memerlukan tambahan anggaran biaya pendidikan.

2) Memerlukan ruang dan tempat memadai jika media yang berukuran besar.

Menurut Daryanto (2011:27) kelemahan media konkret adalah :

1) Tidak bisa menjangkau sasaran dalam jalur besar.

2) Penyimpanannya dalam ruang yang besar.

3) Perawatan cukup rumit.

Jadi kelemahan dari media konkret adalah :
1) Memerlukan anggaran biaya yang besar.

2) Membutuhkan ruangan besar dan perawatan yang cukup rumit.

Pada penelitian ini saya menggunakan model pembelajaran Snowball Trowing dan metode Demonstrasi dengan model Konkret dibawah ini penerapan gabungan pada penelitian ini sebagai berikut:

a) Guru menyampaikan materi yang akan disajikan dengan menggunakan media pembelajaran dan dipraktekan langsung kedepan kelas.

b) Guru membentuk kelompok-kelompok dan memanggil masing-masing ketua kelompok untuk memberikan penjelasan tentang materi.

c) Guru mendemonstrasikan media dan menjelaskan kepada masing-masing ketua kelompok.

d) Masing-masing ketua kelompok kembali kekelompoknya masing-masing kemudian menjelaskan materi yang disampaikan guru kepada teman sekelompoknya.

e) Masing-masing peserta didik diberikan satu lembar kertas kerja untuk menuliskan satu pertanyaan apa saja yang menyangkut materi yang sudah dijelaskan oleh ketua kelompok.

f) Peserta didik membentuk kertas tersebut seperti bola dan dilempar dari satu peserta didik ke siswa yang lain selama+15 menit.

g) Setelah peserta didik mendapat satu bola, ia diberi kesempatan untuk 
Tunas Jurnal Pendidikan Guru Sekolah Dasar, Juni 2019, Volume 1 Nomor 2, (42-54)

ISSN : 2477-6076

menjawab pertanyaan yang ditulis dalam kertas tersebut secara bergantian.

h) Guru mengevaluasi dan menutup pembelajaran.

\section{METODE PENELITIAN}

Penelitian ini menggunakan model Penelitian Tindakan Kelas (PTK) yang direncanakan dengan dua siklus. PTK didefinisikan sebagai suatu bentuk penelitian yang bersifat refleksi dengan melakukan tindakan-tindakan tertentu untuk memperbaiki dan meningkatkan praktik pembelajaran di kelas agar lebih berkualitas sehingga peserta didik dapat memperoleh hasil belajar yang lebih baik. Menurut Rustam dan Mundilarto (Rohimah, 2012:36) PTK merupakan :

Sebuah penelitian yang dilakukan oleh guru di kelasnya sendiri dengan jalan merancang, melaksanakan, dan merefleksikan tindakan secara kolaboratorif artinya peneliti bekerja sama dengan guru kelas dan partisipatif artinya peneliti dibantu teman sejawat sebagai obsever dengan tujuan untuk memperbaiki kinerja sebagai guru sehingga hasil belajar peserta didik dapat meningkat.

Penelitian tindakan kelas dilakukan untuk meningkatkan kualitas pendidikan atau pengajaran yang diselenggarakan oleh guru/peneliti itu sendiri, dengan melibatkan peserta didik melalui tindakan-tindakan yang direncanakan guru sendiri, dilaksanakan sendiri, dan dievaluasi sendiri.
Tindakan tersebut diberikan oleh guru atau dengan arahan dari guru yang dilakukan oleh peserta didik.

Dalam penetian tindakan kelas peneliti mempunyai peran ganda yaitu sebagai peneliti dan sebagai pendidik. Dalam melakukan penelitian ini peneliti tidak hanya hadir pada saat jadwal mengajar melainkan selalu aktif memantau atau meneliti peserta didik di luar jam pelajaran guna memaksimalkan hasil penelitian.

Subjek penelitian dalam penelitian ini adalah peserta didik kelas III B SDN 8 Langkai untuk dijadikan sebagai sumber informasi yang dibutuhkan dalam pengumpulan data. Peserta didik berjumlah 20 peserta didik. Terdiri dari 11 orang peserta didik laki-laki dan 9 orang perempuan. Pengumpulan data yang diperoleh pada penelitian ini melalui pengamatan (observasi) dan tes hasil belajar. Penelitian ini menggunakan metode Penelitian Tindakan Kelas (PTK).

\section{HASIL PENELITIAN}

Hasil pengamatan terhadap aktifitas guru dan peserta didik dalam pembelajaran Matematika pada materi satuan waktu yang menggunakan Model Snowball Trowing dan Metode Demonstrasi dengan berbantuan Media Konkret saat pembelajaran berlangsung dicatat oleh tiga orang observer yaitu guru dan teman sebaya tergambar dalam tabel sebagai berikut: 
Tunas Jurnal Pendidikan Guru Sekolah Dasar, Juni 2019, Volume 1 Nomor 2, (42-54)

ISSN : 2477-6076

\section{Tabel 4.9}

Rekapitulasi Data Pengamatan Aktivitas Guru dan Peserta Didik Dalam Pembelajaran Matematika Materi Satuan Waktu

\begin{tabular}{|l|l|l|l|l|l|}
\hline \multirow{2}{*}{ No } & \multirow{2}{*}{ Aktivitas } & \multicolumn{3}{|l|}{ Rata-Rata Nilai } \\
\cline { 3 - 6 } & & Siklus I & \multicolumn{2}{l|}{ Siklus II } \\
\cline { 3 - 6 } & $\begin{array}{l}\text { Pengamat } \\
\text { I }\end{array}$ & $\begin{array}{l}\text { Pengamat } \\
\text { II }\end{array}$ & $\begin{array}{l}\text { Pengamat } \\
\text { I }\end{array}$ & $\begin{array}{l}\text { Pengamat } \\
\text { II }\end{array}$ \\
\hline $\mathbf{1}$ & $\begin{array}{l}\text { Aktivitas } \\
\text { guru }\end{array}$ & 3,68 & 3,5 & 3,76 & 3,94 \\
\hline $\mathbf{2}$ & $\begin{array}{l}\text { Aktivitas } \\
\text { peserta } \\
\text { didik }\end{array}$ & 3,07 & 3,35 & 3,53 & 3,8 \\
\hline
\end{tabular}

Grafik 4.1

Aktivitas Guru dan Aktivitas Belajar Peserta didik

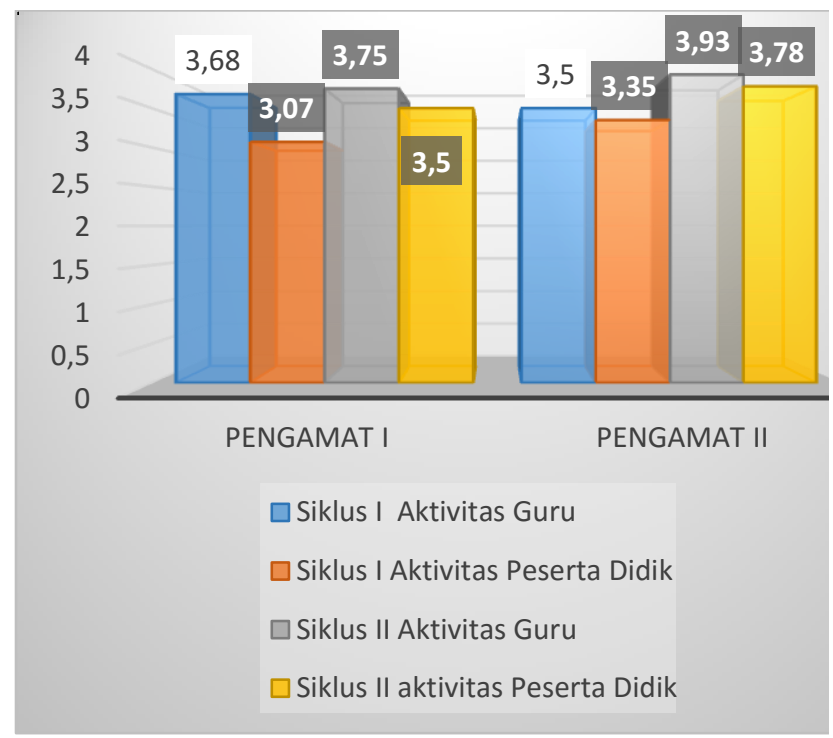

Berdasarkan tabel di atas, melalui pembelajaran menggunakan Model Snowball Trowing dan Metode Demonstrasi dengan berbantuan Media Konkret oleh peneliti di kelas IIIb SDN 8 Langkai
Palangka Raya aktivitas guru dan aktivitas belajar peserta didik menunjukkan perkembangan yang baik. Aktivitas guru dan peserta didik pada siklus I oleh pengamat I memperoleh nilai rata-rata 3,68 dan 3,07 dan pengamat II dengan nilai rata-rata 3,5 dan 3,35. Sedangkan pada siklus II ada peningkatan menjadi lebih baik, dengan penilaian rata-rata oleh pengamat I sebesar 3,76 dan 3,53 dan oleh pengamat II dengan nilai rata-rata 3,94 dan 3,8 .

Hasil belajar yang diperoleh berdasarkan hasil tes pesertaa didik kelas IIIb di SDN 8 Langkai Palangka Raya menggunakan Model Snowball Trowing dan Metode Demonstrasi dengan berbantuan Media Konkret rekapitulasi datanya dapat dilihat sebagai berikut : 
Tunas Jurnal Pendidikan Guru Sekolah Dasar, Juni 2019, Volume 1 Nomor 2, (42-54)

ISSN : 2477-6076

Tabel 4.1

Rekapitulasi Hasil Belajar Matematika Peserta Didik Kelas III-B SDN 8 Langkai Palangka Raya

\begin{tabular}{|c|c|c|c|c|}
\hline \multirow[t]{2}{*}{ No } & \multirow[t]{2}{*}{ Nama } & \multicolumn{3}{|l|}{ Nilai } \\
\hline & & Pretest & Siklus I & Siklus II \\
\hline 1 & MGW & 40 & 66,6 & 86,6 \\
\hline 2 & MI & 86,6 & 66,6 & 93,3 \\
\hline 3 & MAH & 86,6 & 80 & 96,6 \\
\hline 4 & MAS & 26,6 & 33,3 & 73,3 \\
\hline 5 & MMAA & 33,3 & 73,3 & 80 \\
\hline 6 & NNA & 80 & 80 & 96,6 \\
\hline 7 & NVS & 53,3 & 66,6 & 86,6 \\
\hline 8 & NPVA & 40 & 80 & 80 \\
\hline 9 & NHE & 26,6 & 40 & 66,6 \\
\hline 10 & QNA & 60 & 86,66 & 86,6 \\
\hline 11 & RNAD & 86,6 & 93,3 & 100 \\
\hline 12 & RA & 40 & 80 & 80 \\
\hline 13 & RLN & 73,3 & 73,3 & 96,6 \\
\hline 14 & SMLR & 40 & 73,3 & 80 \\
\hline 15 & SV & 20 & 7,33 & 73,3 \\
\hline 16 & TM & 33,3 & 40 & 73,3 \\
\hline 17 & VA & 86,6 & 86,66 & 100 \\
\hline
\end{tabular}


Tunas Jurnal Pendidikan Guru Sekolah Dasar, Juni 2019, Volume 1 Nomor 2, (42-54) ISSN : 2477-6076

\begin{tabular}{|l|l|l|l|l|}
\hline 18 & WM & 26,6 & 33,3 & 66,6 \\
\hline 19 & SA & 33,3 & 73,3 & 80 \\
\hline 20 & NSP & 20 & 46,6 & 60 \\
\hline $\begin{array}{l}\text { JUMLAH } \\
\text { Rata-Rata } \\
\text { Ketuntasan Klasikal }\end{array}$ & 992,7 & $1.346,12$ & 1656 \\
\cline { 2 - 5 } & 49,63 & 67,3 & 8,28 \\
\cline { 2 - 5 } & $30 \%$ & $75 \%$ & $95 \%$ \\
\hline
\end{tabular}

\section{Grafik 4.2}

\section{Hasil Belajar Matematika Materi Satuan Waktu Peserta Didik Kelas IIIb SDN 8 Langkai Palangkaraya}

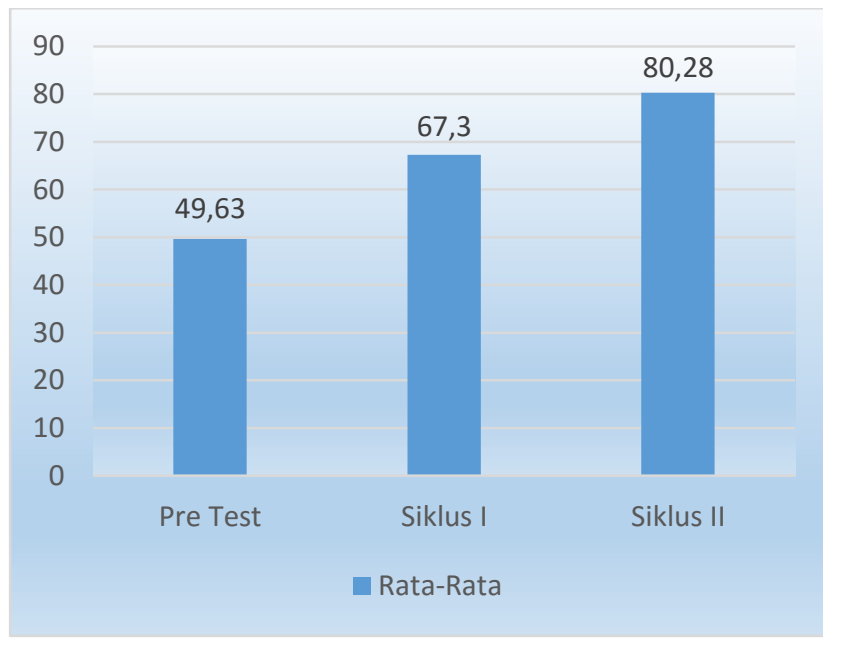

\section{Grafik 4.3}

Ketuntasan Klasikal Peserta Didik Mata Pelajaran Matematika Materi Satuan Waktu Peserta Didik Kelas IIIb SDN 8 Langkai Palangkaraya

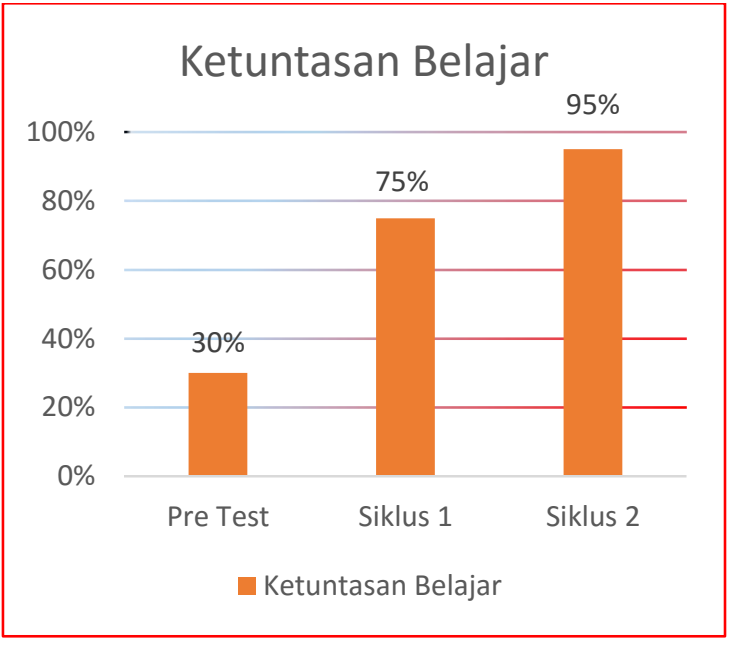

Berdasarkan tabel di atas, dapat dilihat bahwa pada tes awal nilai rata rata peserta didik hanya memperoleh nilai ratarata 49,63. Nilai ini masih kurang dari kriteria ketuntasan minimal yang ditentukan yaitu 65. Hasil ketuntasan belajar secara klasikal juga hanya memperoleh nilai sebesar 30\%, sedangkan kriteria ketuntasan klasikalnya minimal $85 \%$. Kemudian pada siklus I nilai rata-rata peserta didik mengalami peningkatan sebesar 67,3 meskipun masih belum mencapai kriteria ketuntasan minimal, secara klasikal pun masih belum mencapai $85 \%$, karena nilai yang diperoleh pada siklus I hanya sebesar 
Tunas Jurnal Pendidikan Guru Sekolah Dasar, Juni 2019, Volume 1 Nomor 2, (42-54)

ISSN : 2477-6076

75\%. Pada siklus II nilai rata-rata peserta didik mengalami peningkatan cukup bagus dengan perolehan nilai rata-rata 8,28 dengan kriteria ketuntasan secara klasikal mencapai 95\%. Peneliti menganggap pada siklus II ini sudah berhasil karena telah mencapai nilai ketuntasan secara kalsikal.

Berdasarkan hasil penelitian di atas maka pelaksanaan perbaikan dengan menggunakan Model Snowball Trowing dan Metode Demonstrasi dengan berbantuan Media Konkret dapat meningkatkan hasil belajar peserta didik.

\section{KESIMPULAN}

1. Aktivitas belajar peserta didik pada saat pembelajaran Matematika menggunakan model snowball trowing dan metode demonstrasi dengan berbantuan media konkret dalam setiap siklus cukup baik dalam kegiatan belajar mengajar. Terlihat pada Siklus I skor yang diperoleh peserat didik dengan persentase rata-rata dari pengamat I dan II 3,21 dengan kategori baik, kemudian pada siklus II skor yang diperoleh oleh peserta didik meningkat menjadi 3,64 dengan kriteria baik.

2. Ada peningkatan hasil belajar peserta didik dalam pelajaran matematika dengan menggunakan media snowball trowing dan metode demonstrasi dengan berbantuan media konkret. Hal ini dapat dilihat dari perbedaan nilai rata-rata peserta didik sebelum melaksanakan penelitian tindakan kelas.
Sebelum melaksanakan penelitian tindakan kelas atau dilihat dari tes pra tindakan nilai rata-rata yang diperoleh adalah 49,63 dan ketuntasan secara klasikal 30\% dengan kategori sangat kurang tercapai. Nilai rata-rata pada siklus I adalah 67,3 dan ketuntasan secara klasikal $75 \%$ dengan kategori cukup tercapai. Maka siklus I masih dianggap belum berhasil. Nilai rata pada siklus II adalah 8,28 dan ketuntasan secara klasikalnya 95\% dengan kategori sangat tercapai. Dari hasil yang diperoleh tersebut ada peningkatan yang sangat signifikan antara hasil pra tindakan sebelum melakukan penelitian tindakan kelas dengan hasil post tes pada siklus II.

\section{DAFTAR PUSTAKA}

Abdul,Malik.2014.Strategi

Pembelajaran.Bandung:

PT.Remaja Rosdakarya Offset

Daryanto.2011.Media

Pembelajaran.Bandung:

PT.Tutorial Narana Sejahtera

Imas,Kurniasih.2016.Ragam

Pengembangan

Model

Pembelajaran: Kata Pena

Miftahul, Huda. 2013. Model-Model Pengajaran dan Pembelajaran. Yogyakarta: Pustaka Pelajar Offside 
Tunas Jurnal Pendidikan Guru Sekolah Dasar, Juni 2019, Volume 1 Nomor 2, (42-54) ISSN : 2477-6076 